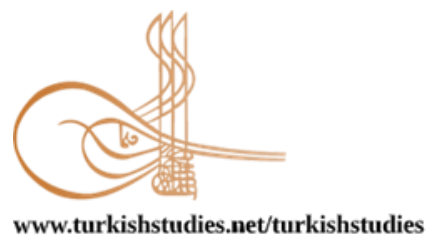

Turkish Studies

www.turkishstudies.net/turkishstudies

eISSN: $1308-2140$

BALKAN
UNTVERSTIT

Sponsored by IBU

Research Article / Araștırma Makalesi

\title{
Covid-19 Salgınının Yönetilmesinde Sosyal Medya Kullanımı: Sağlık Bakanı Fahrettin Koca'nın Resmi Twitter Hesabı Üzerine Bir Analiz
}

\author{
Social Media Use In The Management Of Covid-19 Epidemic: An Analysis On Official Twitter \\ Account Of Minister Of Health Fahrettin Koca
}

Tuba Kalçık* - Ümmü Altan Bayraktar**

\begin{abstract}
The new type of coronavirus epidemic, which was first seen in Wuhan city of Hubey provience of China in December 2019, called 'Covid-19', causing worldwide deaths, destruction in social and economic life on a global scale. In order to combat this process, in which human relations are restricted in order to reduce social interaction as much as possible, many governments have come to the point of using social media effectively in order to manage their crisis, to prevent their services from failing, to protect their reputation, trust and support to the public. The importance and impact of these practices came up once again in this period. In the process of fighting the virüs, many states informed the public through social media channels within the scope of crisis communication. Turkey is one of these countries. In this context; within the framework of the importance of effective communication in times of crisis, the subject of the study; Turkey representative of state party's crisis, taken to medical and logistics measures, control activities, as well as outbreaks of carrying out crisis communication activities of the Ministry of Health, it has detected the first case of March 11, 2020 and March 25, 2020 dates well into the area in a fifteen days time; the analysis of the crisis communication studies carried out by the Minister of Health Fahrettin Koca through his official Twitter acount during the Covid-19 epidemic crisis affecting the country. Content analysis method was used in this study. Within this framework, messages shared within the scope of the crisis communication activities carried out by Fahrettin Koca through his official twitter account during the Covid-19 epidemic, which is a public health crises to which the state is a party; the tweet sharing frequency, tweet sharing type, tweet content and visual tweet contents were analyzed under the main headings using the SPSS program, and the data obtained were evaluated in the context of the literature. In this context, the Minister Fahrettin Koca's twitter account crisis comunication through the process, social media importance and effect, how it is used, if utilized effectively, have been studied to determine whether they contribute results to crisis communication during the date range examined in the coronavirus epidemic process in Turkey, and the findings have shown a succesful communication.
\end{abstract}

\footnotetext{
* Dr. Öğretim Üyesi, İstanbul Medipol Üniversitesi, İletişim Fakültesi, Halkla İlişkiler ve Reklamcılık Bölümü Asst. Prof. Dr., İstanbul Medipol University, Faculty of Communication, Department of Public Relations and Advertising ORCID 0000-0001-9393-8484

tkalcik@medipol.edu.tr

** Dr. Öğretim Üyesi, Girne Amerikan Üniversitesi, İletişim Fakültesi, Basın Yayın Bölümü Asst. Prof. Dr., Girne American University, Faculty of Communication, Department of Journalism and Broadcasting ORCID 0000-0002-7415-5035

ummubayraktar@gau.edu.tr

Cite as/ Atıf: Kalçık, T. \& Altan Bayraktar, Ü. (2020). Covid-19 salgınının yönetilmesinde sosyal medya kullanımı:

Sağlık Bakanı Fahrettin Koca'nın resmi twitter hesabı üzerine bir analiz. Turkish Studies, 15(6), 583-602. https://dx.doi.org/10.7827/TurkishStudies.44484

Received/Geliş: 24 June/Haziran 2020

Accepted/Kabul: 15 October/Ekim 2020

Copyright $\mathbb{C}$ MDE, Turkey

Checked by plagiarism software Published/Yayın: 20 October/Ekim 2020 CC BY-NC 4.0
} 


\section{Structured Abstract: Introduction}

Almost every organization, regardless of the organization's purpose, finds itself in a crisis situation at various times as long as it continues to exist. Moreover, neither the efforts of organizations to prevent a crisis in a certain way can prevent the formation of a crisis, nor can a serious level of pre-crisis preparedness completely eliminate the devastating impact of the crisis. In this context, to exit the crisis with the least damage, to manage the crisis in the most ideal and the most perfect way, the most effective tool is communication in crisis management; the display of a transformational style of action, shaped by public relations policies, using technological possibilities, provides important contributions in the crisis management process in which the state is a party.

The new type Coronavirus outbreak, first seen in December 2019 in Vuhan, Hubey province of China, and dubbed 'Covid-19', has transformed into a global epidemic and caused worldwide deaths, affecting many areas from health services to work, economy to politics, educational institutions, public and private life.

The World Health Organization (WHO) has declared a pandemic and has taken public health into account in many countries with the rapid spread of the epidemic and the increase in deaths. And while decisions and practices are taken to put the negative consequences of the outbreak on the national economies into second place, successive packages of economic measures are announced to prevent the economic devastation caused by the outbreak. Due to the outbreak, the economic activities of institutions and organizations in many countries where extraordinary measures have been taken and who have declared curfews have stopped, remote work has become almost mandatory. In this process, where schools including higher education are closed and education is continued remotely and online, the importance of digital transformation and the use of technology in all areas has been raised once again. The outbreak, which can be transmitted through contact with respiratory droplets rather than air and where the rate of transmission is rising rapidly from mid-January 2020, can have fatal consequences, especially in the elderly and those with systemic diseases. Unfortunately to date there are no vaccines and no specific drugs to prevent or treat the disease. In this process, The World Health Organization and experts report that the most effective way to prevent the outbreak is to avoid contact with other people, such as social distance and isolation. In this context, there have been some measures that states can take against the virus with the priority of developing conditions that threaten public health and good health and maintaining public safety and public order. These included reducing contact between people, maintaining social distance and not leaving the house when it was not necessary.

\section{Purpose/Method}

During this crisis that has affected our country, T.C. The Minister of Health Fahrettin Koca, carried out medical and logistical measures and control activities as well as epidemic crisis communication activities as a representative of the state side of the crisis. Because of this, Koca's social media account was examined. Via his official twitter account; for 15 days period from 11 March 2020, when the first case was officially announced that it had been identified; for 15 days period from March 11, 2020, tweet sharing, tweet sharing type, tweet content and visual tweet content were evaluated and analyzed in the light of the literature.

\section{Findings (Results)}

Within the range of dates examined within the scope of this research, the twitter shares of Health Minister Fahrettin Koca have shown that they actively and effectively use social media facilities in coronavirus crisis communication. Shared content is enriched with videos and photos. These content has been shared and disseminated with the features provided by social media media. Especially with the detection of the first case, it was observed that the public was informed momentarily by taking care of transparency, which is one of the most important components of the crisis communication process without causing anxiety and panic, and by preventing the information pollution circulating on social media. During the crisis period, when the importance and influence of social media was brought back on the agenda, Minister Koca showed that social media has a positive effect on the establishment or strengthening of trust in the institution as a representative of the state. The scope of the research focus on social media and in particular twitter, thanks to the facilities it provides to its users, the institutions have the opportunity to express themselves more easily and easier to find support for reasons Covid-19 crisis communication the process more transparent, faster and more reliable in maintaining a way has helped.

Keywords: Crisis Managemet, Crisis Communication, Social Media, Twitter, Covid-19 
Öz: İlk kez 2019 yılı Aralık ayında Çin'in Hubey eyaletine bağlı Vuhan kentinde görülen ve 'Covid-19' olarak adlandırılan, küresel salgına dönüşerek dünya çapında ölümlere neden olan yeni tip koronavirüs salgınının, küresel boyutta insan sağlığı başta olmak üzere toplumsal ve ekonomik hayatta tahribatlar yaratmaya devam ettiği, sosyal etkileşimi mümkün olduğunca azaltabilmek üzere insan ilişkilerinin zorunlu olarak kısıtlandığı bu süreçle mücadelede birçok devlet krizi yönetebilmek, hizmetlerinin aksamaması, kurum itibarının, halka güven ve desteğinin zedelenmemesi ya da kaybedilmemesi için sosyal medyayı etkin olarak kullanma noktasına gelmiştir ve bu uygulamaların önemi ve etkisi bir kez daha gündeme gelmiştir. Virüsle mücadele sürecinde birçok devlet kriz iletişimi kapsamında sosyal medya kanallarıyla kamuoyunu bilgilendirmiştir. Türkiye de bu ülkelerden biridir. Bu kapsamda; kriz dönemlerinde etkili iletişimin önemi çerçevesinde, çalışmanın konusu; Türkiye'de krizin tarafı devleti temsilen, alınacak tıbbi ve lojistik önlemlerle kontrol faaliyetlerinin yanı sıra salgın kriz iletişim faaliyetlerini yürüten Sağlık Bakanlığı'nın, ilk vakanın tespit edildiğinin resmi olarak açıklandığı 11 Mart 2020 ve 25 Mart 2020 tarihlerini de içine alan on beş günlük süre içinde; ülkeyi etkileyen Covid-19 salgını krizinde Sağlık Bakanı Fahrettin Koca'nın resmi twitter hesabı üzerinden gerçekleştirdiği kriz iletişimi çalışmalarının incelenmesidir. Çalışmada içerik analizi yöntemi kullanılmıştır. Bu çerçevede, devletin taraf olduğu bir halk sağlığı krizi olan Covid-19 salgını sürecinde Bakan Fahrettin Koca'nın resmi twitter hesabı üzerinden yürüttüğü kriz iletişim faaliyetleri kapsamında paylaşılan iletiler; tweet paylaşım sıklığı, tweet paylaşım türü, tweet içeriği ve görsel tweet içerikleri ana başlıkları altında SPSS programı kullanılarak analiz edilmiş, elde edilen veriler literatür ışığında değerlendirmeye tabi tutulmuştur. Bu bağlamda, Bakan Koca'nın twitter hesabı üzerinden yürüttüğü kriz iletişimi sürecinde, sosyal medyanın önemi ve etkisi, nasıl kullanıldığı, etkin kullanıldığı taktirde kriz iletişimine nasıl katkı sağladığının belirlenmesine yönelik olarak yapılan çalışma, Türkiye'de koronavirüs salgını sürecinde incelenen tarih aralığında başarılı bir kriz iletişiminin gerçekleştirilmiş olduğunu göstermiştir.

Anahtar Kelimeler: Kriz Yönetimi, Kriz İletişimi, Sosyal Medya, Twitter, Covid-19

\section{Giriş}

Kuruluş amacı ne olursa olsun hemen her örgüt varlığını devam ettirdiği sürece çeşitli zamanlarda kendini bir kriz durumunun içinde bulmaktadır. Üstelik ne örgütlerin krizi önleme çabaları bir krizin oluşumunu kesin bir şekilde önleyebilmekte, ne de kriz öncesi ciddi bir hazırlık düzeyi krizin yıkıcı etkisini tam olarak ortadan kaldırabilmektedir. Bu çerçevede krizden en az hasarla çıkmak, krizi en ideal ve en kusursuz şekilde yönetebilmek için en etkili aracın iletişim olduğu kriz yönetiminde; halkla ilişkiler politikalarıyla şekillenen, teknolojik olanaklardan faydalanarak dönüşümcü bir hareket tarzı sergilenmesi devletin de taraf olduğu kriz yönetimi sürecinde önemli katkılar sağlamaktadır.

İlk kez 2019 yılı Aralık ayında Çin'in Hubey eyaletine bağlı Vuhan kentinde görülen ve 'Covid-19' olarak adlandırılan, küresel salgına dönüşerek dünya çapında ölümlere neden olan yeni tip koronavirüs salgını sağlık hizmetlerinden çalışma hayatına, ekonomiden siyasete, eğitim kurumlarına, kamusal alandan özel hayata kadar pek çok alanı etkilemiştir. Öncelikle bir sağlık sorunu olarak tüm dünyayı etkisi altına alan ve Dünya Sağlık Örgütü (DSÖ) tarafından pandemi ${ }^{1}$ ilan edilen salgının hızla yayılması ve ölümlerin artmasıyla birlikte çok sayıda ülkede halk sağlığını dikkate alan ve salgının ülke ekonomilerinde yaratacağı olumsuz sonuçların ikinci plana itildiği kararlar alınırken, diğer yandan da salgının yarattığı ekonomik tahribatın önüne geçmek için peş peşe ekonomik tedbir paketleri açıklanmaktadır. Salgın nedeniyle olağanüstü önlemlerin alındığı, sokağa çıkma yasağı ilan eden çok sayıda ülkede kurum ve kuruluşların ekonomik faaliyetlerinin durduğu/yavaşladığı, uzaktan çalışmanın neredeyse zorunlu hale geldiği, yüksek öğretim dahil okulların kapatılarak eğitime uzaktan, online olarak devam edildiği bu süreçte, her alanda dijital dönüşüm ve teknoloji kullanımının gerekliliğinin önemi bir kez daha gündeme gelmiştir.

\footnotetext{
${ }^{1}$ Pandemiler veya pandemik hastalıklar, bir kıta, hatta tüm dünya yüzeyi gibi çok geniş bir alanda yayılan ve etkisini gösteren salgın hastalıklara (epidemi) verilen genel addır.
} 
Havadan ziyade, solunum damlacıkları ile temas yoluyla bulaşabilen ve Ocak 2020 ortasından itibaren bulaşma oranının hızla yükselişe geçtiği salgın, özellikle yaşlılar ile sistemik hastalıkları olanlarda ölümcül sonuçlara yol açabilmekte ve bugüne kadar hastalığı önlemek veya tedavi etmek için aşı ve spesifik bir ilaç bulunmamaktadır. Bu süreçte DSÖ ve konunun uzmanları salgından korunmanın yollarından en etkili yöntemin diğer insanlarla temastan kaçınmak anlamına gelen sosyal mesafe ve kişilerin kendilerini tecrit etmesi olduğunu bildirmektedir. Bu çerçevede halkın sağlığını ve iyilik halini tehdit eden koşulların gelişmesi ile halkın güvenliği ve kamu düzeninin sürdürülmesi önceliği ile devletlerin virüse karşı alabildikleri en net tedbirler; insanlar arası temasın azaltılması, sosyal mesafenin korunması ve gerekli olmadığı hallerde evden çıkılmaması yönünde olmuştur.

Covid-19 salgınının küresel boyutta insan sağllğı başta olmak üzere toplumsal ve ekonomik hayatta tahribatlar yaratmaya devam ettiği bu süreçle mücadelede etkili ve başarılı bir kriz yönetimi 'her şeyden önce hedef kitlelerin krize neden olan konuya ya da duruma ilişkin zaman kaybedilmeksizin hızlı bir biçimde, doğru bilgilerle, alanında uzman kişiler tarafından, farklı araç ve yöntemlerin yerinde kullanılarak gerekli mesajların anlaşılır şekilde kodlanarak bilgilendirilmesi' (Akdağ \& Arklan, 2013: 43) ile mümkün olacaktır. Sosyal etkileşimi mümkün olduğunca azaltabilmek üzere insan ilişkilerinin zorunlu olarak kısıtlandığı bu süreçte, birçok devlet krizi yönetebilmek, hizmetlerinin aksamaması, kurum itibarının, halka güven ve desteğinin zedelenmemesi ya da kaybedilmemesi için sosyal medyayı etkin olarak kullanma noktasına gelmiştir ve bu uygulamaların önemi ve etkisi bir kez daha gündeme gelmiştir. Bu süreçte 'etkileşim kanallarının daha çok çeşitlendirilebileceği düşünülmekle beraber sosyal ağların devletlerin iletişim yönetiminde önemli yeri olduğu kanısına varılmıştır' (Mazıc1, 2020: 1087). Virüsle mücadele sürecinde birçok devlet kriz iletişimi kapsamında sosyal medya kanalıyla kamuoyunu bilgilendirmiştir. Türkiye de bu ülkelerden biridir.

Bir tarafında devletin, diğer tarafinda halkın ve medyanın durduğu salgının yol açtığı krizde devletin asıl amac1, salgını tıbbi olarak kontrol etmek ve yayılmasını önlemektir. Bunu gerçekleştirmesinin yolu ise krizin tarafı olan devletin, halk ve medyaya güvenilir, şeffaf ve her kesime ulaşabilen enformasyon akışışını sağlamasından geçmektedir. Bu çerçevede kriz durumlarında kuruluşlar eğer krizin geldiğinin farkında ise; kriz öncesi dönemde kendini ifade etmek, ne kadar hazırlıklı olduğunu göstermek, kriz aşamasında ise; krizi kontrol altında tuttuğunu, neler yaptığını ve yapacağını anlatmak, halkın da buna karşılık ne yapması gerektiğini bilgi, tavsiye ve gerekirse direktif vererek anlatması devletin en temel görevlerinden biri olan halkın iyilik halini sürdürmesi için büyük önem taşımaktadır.

Kriz dönemleri, olağan koşulların devam ettiği dönemlerden farklı davranış, politika, uygun ve etkili iletişim planları ve stratejilerini gerektirmektedir. Bunun için; devletin taraf olduğu krizlerde, krizden sorumlu kurum ve yöneticilerinin halka mümkün olduğu kadar hızlı, güncel ve doğru bilgiler verebilmesi uygun iletişim kanallarının seçimi ve uygulanacak özel iletişim stratejileriyle mümkün olacaktır. Böylelikle krizin doğru bir biçimde yönetildiği konusunda zihinlerdeki kuşkular büyük oranda giderilerek, halkın mevcut duruma ilişkin doğru bir biçimde bilgilenmesi ile güven ortamı oluşturulacak, tavsiye ve uyarıların büyük oranda dikkate alınması sağlanmış olacaktır. Bu bağlamda, kriz durumlarında günümüzde halka en hızlı biçimde ulaşmak ve halkla konuşmak için başvurulabilecek en önemli iletişim kanallarından olan; katılım, işbirliği, paylaşım, gerçek zamanlı erişim, şeffaflık, açıklık, zamandan ve mekândan bağımsızlık, iki yönlü iletişim gibi özelliklere barındıran, internet ve web tabanlı son teknolojilerin adeta odak noktası haline gelen sosyal medya önemli olanaklar sağlamaktadır.

Koronavirüs henüz Türkiye'de etki göstermeden hazırlıklara başlayarak önemli tedbirler alan, olası salgınlara karşı bilim kurulu oluşturan Sağlık Bakanlığı; kriz yönetiminde en temel unsur olan ve en genel tanımıyla 'kriz öncesi, kriz anı ve kriz sonrası örgüt ile paydaşları arasındaki diyalog 
süreci' (Fearn-Banks, 2011: 2) olarak tanımlanabilen ve seçilecek ve uygulanacak iletişim stratejilerinin doğru belirlenmesinin kilit rol oynayacağı salgın kriz iletişiminde, Sağlık Bakanı Fahrettin Koca'nın Twitter paylaşımları ülkenin en popüler hesabı durumuna yükseldi ve Türkiye bütün gelişmeleri tek elden Sağlık Bakanı'nın resmi twitter hesabı üzerinden yaptığı açıklamalardan takip etmeye başladı. Bu süreçte; Bakan Fahrettin Koca krizden etkileneceklerle; günümüzdeki en etkili iletişim kanalı olan sosyal medya ve olanaklarını kullanarak; özellikle ilk vakanın görülmesinden sonra ortaya çıkan güven çaresizliğini ortadan kaldırabilmek ve durumun ciddiyetinin kavranmasına yardımcı olmak; bilim kurulu üyelerinin ve özellikle salgının ortaya çıktığı Çin başta olmak üzere dünyadaki bütün tecrübelerin takip edilerek, olağan gelişmeler konusunda halk1 zamanında, şeffaf bir şekilde, dezenformasyona karşı uyarı ve bilgilendirmelerle devamlı olarak vatandaşların evde kalmasına yönelik motivasyon sağlayacak farklı formatlarda hazırlanan içeriklerle uyarılar yapmıştır.

Bu kapsamda; kriz dönemlerinde etkili iletişimin önemi çerçevesinde çalışmanın konusu; Türkiye'de krizin tarafı devleti temsilen, alınacak tıbbi ve lojistik önlemlerle kontrol faaliyetlerinin yanı sıra salgın kriz iletişim faaliyetlerini yürüten Sağlık Bakanlığı'nın ilk vakanın tespit edildiğinin resmi olarak açıklandığ 11 Mart 2020 ve 25 Mart 2020 tarihlerini de içine alan on beş günlük süre içinde; ülkeyi etkileyen Covid-19 salgını krizinde Sağlık Bakanı Fahrettin Koca'nın resmi twitter hesabı üzerinden gerçekleştirdiği kriz iletişimi çalışmalarının incelenmesidir.

$\mathrm{Bu}$ çerçevede çalışmanın ilk kısmında kriz kavramı, kriz yönetimi, kriz yönetiminin bir bileşeni olarak kriz iletişimi, kriz iletişim yönetimi ve sosyal medya kavramları incelenmiş, çalışmanın analiz kısmında ise devletin taraf olduğu bir halk sağlığı krizi olan Covid-19 pandemisi sürecinde T.C. Sağlık Bakanı Fahrettin Koca'nın resmi twitter hesabı üzerinden yürüttüğü kriz iletişim faaliyetleri; ilk vakanın tespit edildiğinin resmi olarak açıklandığı 11 Mart 2020 tarihinden itibaren on beş günlük süreyle; tweet paylaşımı, tweet paylaşım türü, tweet içeriği ve görsel tweet içerikleri, literatür 1 şığıında değerlendirilerek analiz edilmiştir.

\section{Kriz İletişim Yönetimi \\ 1.1. Kriz Kavramı}

Literatürde pek çok bilim alanına göre farklı tanımlarına rastladığımız, üzerinde fikir birliği olmayan kriz kavramı; 'bir kuruluşun rutin sistemini bozan ve birdenbire ortaya çıkan herhangi bir acil durum' (Okay \& Okay, 2005: 327), 'beklenilmeyen ve önceden sezilemeyen, ancak hemen karşılık verilmesi gereken, kuruluşun yaşama, uyum ve savunma mekanizmalarını yetersiz hale getirerek mevcut değerlerini, amaçlarını ve imajını tehdit eden gerilim durumu' (Kazanc1, 2004: 310), 'bireyin, grubun veya örgütün normal rutin prosedürlerin/uygulamaların kullanılmasıyla baş edemedikleri ve ortaya çıkan ani değiş̧imin, stres yarattı̆̆ı bir durum' (Booth, 1993: 85-86), 'örgütün varlığını tehlikeye sokan veya varlığını sürdürmesini olanaksız hale getiren, ani olarak ortaya çıkan ve ivedi olarak tepki gösterilmesini gerektiren; örgütün krizi öngörme ve önleme mekanizmalarının yetersiz kaldığ 1 gerilim oluşturan, plansız ve istenmeyen bir durumdur' (Akt. Tengilimoğlu \& Öztürk, 2004:173) şeklinde tanımlanmaktadır. Düzen halinin, büyük bir tehdit ve tehlikelerle karş1 karşıya kalmasının yanı sıra beklenmeyen bir olay sebebiyle bozulması, istikrarsızlık durumu anlamına da gelen kriz, 'kimi zaman bir durum olabileceği gibi tehdidin olası etkilerine ve gelişmesine bağlı olarak bir süreç haline gelebilmektedir' (Gülgün, 2011: 6). Kriz kavramına ilişkin yapılan tanımlar incelendiğinde hemen hemen tüm tanımların ortak noktasının 'krizlerin arzu edilmeyen durumlar yaratması, bir tehlike ve tehdide bağlı olarak gelişmesi, mevcut düzeni bozması, belirsizlik ve bilinmeyeni içerebilmesi, özel bir planlama ve yönetim gerektirmesi, acil ve zamanında müdahale gerektirmesi' (Gülgün, 2011: 13) ne işaret ettiği görülmektedir. Kriz ortamını örgütlerin minimum düzeyde zarar görecek şekilde atlaması için de gerekli süreci en etkili biçimde yönetebilmek amacıyla ivedilikle ve doğru zamanlama ile gerekli olan planlama ve faaliyeti yapması gerekmektedir. 
Krizlere neden olan olaylar çok çeşitlidir. Krizler ortaya çıkış nedenlerine göre; kuruluş içinden doğabileceği gibi, çevrede oluşan faktörlerin etkisiyle de oluşabilir. 'İşletme yapısının eskiyip bozulması, yönetimin beceriksizliği, birden aşırı büyüme krize yol açan iç etmenlerdir. Bunun yanında ekonomik sistem istikrarsızlığı, teknolojik değişiklikler, siyasal ve hukuki etmenler, kamu yönetiminin zaafı, uluslararası pazarlarda fiyat dalgalanmaları, savaş çıkması, deprem, sel, yangın gibi doğal yıkımlar krizlere yol açabilir. Bunlar da dış etmenlerdir' (Kazancı, 2004: 310). Bunlara ek olarak günümüzde giderek artan çevre riskleri, biyo-terorizm, terörist saldırılar, halk sağllğı tehditleri de dış etmenler arasında sayılabilen kriz nedenlerindendir. Kriz ile ilgili çeşitli alanlarda yapılan çalışmalara ve araştırmalara bakıldığında tek bir sınıflandırma olmadığı görülmekle birlikte; krizlerin ortaya çıkış şekilleri, nedenleri, süreçleri ve sonuçları gibi unsurlara bağlı olarak değerlendirildiği görülmektedir. Yapılan bir sınıflandırmaya göre 'krizler ani ortaya çıkan krizler ve yavaş ortaya çıkan krizler' (Arslan, 2009: 182) olarak ele alınmakta, 'risklere göre sınıflandırıldığında ise krizler kontrol edilebilir ve bilinen (ekonomik, siyasal, yönetimsel vb.), kontrol edilemez ve engellenemez (doğal afetler) ve bilinmeyen ve beklenmeyen (terör, şarbon vb.) olmak üzere üç gruba ayrılmaktadır' (Ulutaş, 2010: 16). Ayrıca, doğrudan paydaşları, kuruluşu, hem kuruluş hem de paydaşları, her ikisini de etkilemeyen krizler (Akt. Gülgün, 2011: 17) olmak üzere yapılan sınıflandırmalar da vardır. Etki alanları göz önüne alarak yapılan kriz sınıflandırmalarına bakıldığı zaman ise; bölgesel, ulusal, uluslararası ve küresel krizler olarak da ayrım yapıldığ1 görülmektedir. 'Küresel krizler, krizin niteliğine göre, uluslararası sistemi büyük ölçüde etkileyen, değiştiren veya dönüştüren krizlerdir. Söz konusu krizlerden biri; insanlık tarihi kadar eski olan ve uluslararası sistem üzerinde çok ciddi ekonomik, siyasi, sosyal ve toplumsal etkilere yol açan pandemilerdir' (Oğurlu, 2020: 791).

Araştırma konusu çerçevesinde ele alınan, dış faktörlü kriz nedenleri arasında yer alan halk sağlığı tehditleri kapsamında kriz oluşturan sebeplerden bir tanesi de salgın hastalıklardır. Bu çerçevede araştırmaya konu olan Covid-19 pandemisi de halk sağlığını tehdit eden kriz sebebi olarak değerlendirilmekte, insan yaşamı başta olmak üzere, mevcut düzeni bozarak kurumların işleyiş ve işlemlerine yönelik tehditler oluşturarak küresel düzeyde olumsuz etkiler doğurmaktadır. $\mathrm{Bu}$ bağlamda, salgın hastalıklar ve pandemi gibi kitlesel insan kayıplarına sebep olan, toplumun genelini ilgilendiren ve devletin de taraf olduğu sağlık krizlerinin, krizin derecesinin artmasında veya azalmasında etkin yönetim anlayışının büyük önem taşıyacağından yola çıkılarak; daha kapsamlı ve geniş ölçekli özel bir planlama ve yönetim gerektireceği bilinmektedir.

\subsection{Kriz Yönetimi}

Kuruluş amacı ne olursa olsun tüm örgütsel yapılar belli amaçlara ulaşma hedeflerini gerçekleştirmek ve bu doğrultuda ürün, hizmet sunmak için var olurlar. İster özel ister kamu sektörü olsun; tüm örgütsel yapıların ortak noktası bu amaçlarını gerçekleştirmek üzere yönetim mekanizmalarına sahip olmalarıdır. Bu amaçlar doğrultusunda faaliyetlerini sürdürürken hemen her örgüt çeşitli zamanlarda kendini bir kriz durumunun içinde bulabilmektedir. Bu çerçevede her kurumun karşı karşıya kalma ihtimali bulunan kriz durumu kamu yönetimi ve bünyesinde faaliyet gösteren kurum ve kuruluşlar için de geçerlidir.

'Krizlerin çeşidi, süreci ve nedeni ne olursa olsun; özel durumlar olmaları nedeniyle bir kuruluş için kriz söz konusu olduğunda özel bir yönetim şekli gerekmektedir' (Gülgün, 2011: 19). $\mathrm{Bu}$ özel yönetim biçimi; yasalar, kurallar ve kriz ortamına bağlı olarak gelişen şartlara uygun olağandışı önlemler, hızlı yanıt gibi öncelikli planlamaları içerir. Bu çerçevede kriz yönetimi; 'bir kriz ya da olumsuz bir durum için stratejik planlama sürecidir, bazı riskleri ve olumsuza dönüşebilecek belirsizlikleri ortadan kaldırma sürecidir ve bu yolla organizasyonun kendi kaderini kontrol etmesine izin vermektedir' (Ural, 2006: 95) şeklinde tanımlanmaktadır. 'Gerçekleşme ihtimali olan ya da başlayan bir kriz sürecinin analiz edilip, krizlerin ortaya çıkmasını sağlayan problemleri çözebilme ve kriz sürecini en az kayıpla atlatabilme faaliyetleri’ (Tengilimoğlu \& 
Öztürk, 2004: 184) olarak da tanımlanabilen kriz yönetimi, seri faaliyetleri içeren bir süreçtir. Sürdürülecek kriz yönetimi faaliyetleri, kamu kurumlarında da diğer sektörlerde olduğu gibi kriz öncesi dönem, kriz dönemi ve kriz sonrası dönem olmak üzere; bu aşamalara uygun olarak geliştirilir ve kamu kuruluşlarında da etkin bir kriz yönetimi, hazırlık ve etkili bir kriz yönetim planlamasını gerektirir.

Kriz yönetimi ve iletişimine yönelik araştırmaları ile oldukça öne çıkan Coombs, günümüzde araştırmacıların ve uygulamacıların büyük çoğunluğunun kriz yönetimi için, yaratıcısı belli olmayan ancak birçok araştırmacı tarafından meta-model olarak kullanılan genel üç aşamalı (kriz öncesi, kriz ve kriz sonrası dönem) yaklaşımı kullandığını, çünkü bu modelin diğer modelleri de içine aldığını belirtmektedir. Bu yaklaşıma göre;

'Kriz öncesi dönem, potansiyel krizlerin kestirilmesi ve etkisinin azaltulabilmesi amaçlarıyla hazırlıkların yapıldı̆̆ ve olası krize karşı hazırlık stratejileri ile ilgili olarak kilit paydaşlar ile iletişim kurulan aşamadır. Krizin gerçekten yaşanmakta olduğu kriz aşaması aciliyet, çeşittlilik ve kestirilemezlik sebepleriyle en zor aşamadır. Bu aşamada kurumsal çalışmalar, kuruluşun krizden başarı ile çıkabilmesi için kritik önem taşımaktadır. Kuruluşun kriz deneyiminden sonra da varlığını devam ettirebilmesine, kurumsal itibarı korunması veya restore edilmesine ve kuruluşun işleyişini sürdürebilecek şekilde ayakta kalmasına yönelik çalışmaları içermektedir. Bu aşamada gerçekleştirilen kriz iletişimi bilgi toplanmasını, bilginin şekillendirilmesini ve paydaşlar ile paylaşılmasın içermektedir. Kriz sonrası dönem ise değerlendirme, uygun yeni önlemlerin alınması ve planların gözden geçirilmesi çalışmalarını içermektedir' (Akt. Coombs, 2010: 3).

Kamu yönetimi ve bünyesindeki kurum ve kuruluşların 'toplumsal yaşamda üstlendikleri roller, yerine getirdikleri işlevler, ulaşmak istedikleri amaçlar ve toplum tarafindan kendilerine yüklenen misyon çok farklı nitelikler taşıdığından kriz yönetimi diğer kurumlara nazaran çok daha büyük önem taşımaktadır. Bu çerçevede, toplumun her kesimine yönelik hizmet verildiği, hizmetlerinin kesintisizliğinin önemi ve çok daha büyük beklentileri tatmin etmek mecburiyeti olduğu için daha kapsamlı kriz yönetimine ihtiyaç duyulmaktadır. Bu çerçevede kriz yönetim planlarının tüm vatandaşların, sosyal paydaşların ihtiyaçlarına göre belirlenmesi ve bunları dikkate alarak hazırlanması gerekmektedir. Çünkü, kamu kuruluşlarında sürdürülen kriz yönetiminin başarısızlığı, kuruluşun güvenilirliğinin, işlerliğinin ve yeterliliğinin sorgulanmasına yol açabilecek, özellikle araştırmaya konu olan halk sağlı̆̆ krizlerinde doğru, şeffaf ve zamanında müdahale sağlanamamasından kaynaklanacak yönetim hataları yönetimin meşruluğu üzerinde de olumsuz sonuçlar doğurabilecektir. Bu noktada kamu kuruluşlarında kriz yönetiminde; ülkedeki mevcut yasal düzenlemelere uygun, mevcut iktidarların anlayış ve politikalarının etkisi ile propaganda aracı yapılmadan, etik ilkelere bağlı, kurumun paydaşlarının ihtiyaçlarına karşı hassas olma zorunluluğu ve sürdürülebilirlik anlayışı ile; alınacak kararların sonuçlarının ekonomik ve finansal boyutlarının göz önüne alındığı sosyal sorumluluğun temel alınması gerekmektedir.

Geniş bir paydaş yelpazesi olan kamu kuruluşlarında başarılı bir kriz yönetiminde, özellikle halk sağlığını tehdit eden krizlerle mücadelede öncelik halkın sağlığı ve güvenliğidir. Bu çerçevede 'krizlerin kamu güvenliği, finansal kayıp ve itibar kaybı olmak üzere üç tehdit yaratabileceğini öne süren Coombs'a göre etkili kriz yönetiminde, ilk öncelik kamu güvenliğine verilmelidir. Çünkü bir kuruluşun ve paydaşlarının tehditlerden korunması ve/veya tehditlerin yarattığı etkinin azaltılması için tasarlanana kriz yönetiminde kamu güvenliğini sağlamadaki bir hata, krizin etkilerini daha da şiddetlendirecektir. Bu bağlamda, insan sağlığını tehdit eden pandeminin yarattı̆̆ kriz durumunda asıl amaç, salgının yayılmasını önlemek ve bu çerçevede kamu güvenliğini sağlamaktır. Bu çerçevede krizin yönetilmesinde kriz iletişiminin önemi büyüktür. Bu bağlamda; krizin tarafları arasında güvene dayalı, şeffaf, anlaşılır ve herkese ulaşan bir iletişim temin edilmesi gerekmekte; iletişim kanallarının doğru ve yerinde kullanılması büyük önem taşımaktadır. 
Araştırmaya konu olan halk sağlığ kaynaklı kriz dönemlerinde, önceliği diğer zamanlarda olduğundan daha fazla halka vermek durumunda olan kamu kurum ve kuruluşlarında geleneksel iletişim araçları yanında yeni iletişim teknolojilerinin sağladığı olanakları kullanılarak halk ile etkili iletişim kurulur ise kriz yönetiminde başarı sağlanabilecek, kurum açısından yeni firsatlar da yaratılabilecektir. Çünkü 'kriz yönetiminde koordinasyon ve tüm kanallardan iletişimin doğru, kesintisiz biçimde sağlanması çok önemlidir' (Genç, 2009: 10).

\subsection{Kriz İletişimi}

Kriz yönetimi, öncelikle bir stratejik yönetim planlamasıdır ve krizin türüne göre, farklı bilim alanları ve disiplinlerin bir arada çalışmasını gerektiren bir süreçtir. Bu alanlardan birisi de iletişimdir. 'Kriz yönetim planı ya da kriz iletişim planı bir kriz ile karşılaşmadan önce hazırlıklı olmak ve kriz durumuna yanıt verebilmek için temel araçlardır. Bu bağlamda kriz, özel bir yönetim gerektirdiği gibi özel bir iletişim çalışması da gerektirir. Bu özel iletişim çalışması kriz iletişimidir (Gülgün, 2011: 35).

'Kriz yönetimi; krizin teknik anlamda yönetimine yoğunlaşırken, kriz iletişimi yaşanmakta olan kriz gerçeği ve alınan önlemlerin algılanmasına yönelik stratejilerin geliştirilmesi ve uygulanmasıdır' (Kadıbeşgil, 2001: 55). Genel çerçevede, kriz yönetiminin temel faaliyeti olarak bir kriz durumu ile başa çıkabilmek için sürecin aşamalarına uygun olarak gerekli bilgilerin toplanması, işlenmesi ve hedef kitle/paydaşlar ile paylaşılması olarak tanımlanabilen kriz iletişiminin; 'olumsuzluk ortaya çıkmadan, olumsuzluk sırasında ve sonrasında organizasyon ile hedef kitleleri arasındaki diyalog' (Ural, 2006: 95), 'dürüst, hızlı, doğru bir yaklaşımla krizden etkilenen kesimlere spesifik bir olayı açıklama, olası sonuçlarını belirleme ve krizden kaynaklanan zararı azaltma amacıyla bilgi ulaştırma çabaları' (Reynolds ve Seeger, 2005: 46), 'kuruluş ve paydaşlar arasında olumsuz bir olay olmadan önce, olay sırasında ve olaydan sonra sözlü, görsel ve/veya yazılı etkileşim-diyalogdur ve bu diyalog kuruluşun imajına yönelik zararı en aza indirmek üzere tasarlanmış strateji ve taktikleri düzenlemektedir' (Gülgün, 2011: 36) şeklinde tanımları yapılmıştır. Kriz iletişimi ister özel sektör ister kamu kuruluşu olsun, kriz durumlarında krizin etkisini azaltmak, kriz üzerinde kontrol sağlamak ve krizi yönetmek amacıyla kullanılan yanıt mekanizmalarının başında gelir.

Araştırmaya konu olan; halkın sağlı̆̆ını ve iyilik halini tehdit eden salgın hastalıklardan kaynaklanan devletin taraf olduğu ve halkın güvenliğinin en temel öncelik haline geldiği kriz durumlarında, halk kendini ve yakınlarını koruyabilmek için bilgiye ve tavsiyeye ihtiyaç duyar ve bu ihtiyaç olağan dönemlerden farklı olarak en üst seviyeye ulaşır. Devletin asıl amacının salgını tıbbi olarak kontrol etmek, yayılmasını önlemek ve oluşacak güven çaresizliğini ortadan kaldırabilmek olacağ1 bu tür kriz durumlarında bunun sağlanabilmesi için krizin tarafları olan devlet ve halk arasında daha kapsamlı ve dikkat gerektiren, yoğun, güvene dayalı, şeffaf, anlaşılır ve herkese ulaşan bir iletişimin temin edilmesi gerekmektedir. Bu çerçevede kriz iletişiminde en önemli bileşenlerin başında güven gelir. Araştırmalar, halkın açık ve samimi bir şekilde bilgilendirildiği durumlarda güvene bağlı olarak paniğin daha az geliştiğini göstermektedir. Aksi durumda; halkın güveninin kaybedilmesi, verilmek istenen tüm bilgi ve mesajların şüphe ile karşılanmasına, sorgulanmasına yol açacak, özellikle günümüz yeni medya düzeninin sağladığı olanakların etkisiyle halkın kendisi bilgiye ulaşma ve üretme eğilimi gösterecektir. Bu durum da iletişimin karar alma sürecini ve etkinliğini olumsuz yönde etkileyecektir.

Salgın kriz iletişiminde önemli bir diğer bileşen de halk ve medya ile en kısa sürede iletişime geçmek ve halkın kendisinin ve ailesinin sağlığını etkileyecek bilgiye ulaşma hakkının gerçekleştirilmesidir. Hızla yayılma ve bulaşma riski taşıması nedeniyle salgın tehdidinin teyit edilmesiyle birlikte; devletin krizi yönetmekle görevlendirdiği kurum ve yöneticileri tarafından yapılacak resmi açıklamaların mümkün olan en kısa sürede yapılması; tehdidin büyümesi ve olası can kayıplarının önlenmesi ve hastalı̆̆ belli bir bölgede kontrol altında alabilmek açısından büyük 
önem taşımaktadır ve kuruma olan güveni güçlendireceği gibi, krizin ilerleyen safhalarında kurumun bilgi üzerindeki kontrolünü de sağlamlaştıracaktır. Çünkü yapılacak açıklamalar ve bilgilendirmelerde yaşanacak gecikme her iki taraf için de son derece yıkıcı sonuçlara sebebiyet verebilecek; halk büyük bir endişe ve panik yaşayabilecektir. Kriz yönetiminden sorumlu kurum ve yöneticileri, resmi duyuruyu halk ile en kısa sürede paylaşırken; kullanılacak bilgilerin yanlış ve eksik olmaması için gereken titizliği göstererek bilgileri dikkatle seçmelidir ve paylaşılacak bilgi ve verilerin daha fazla bilgi alındığında değişebileceği bilgisi verilerek güncelleme yapılacağı belirtilmelidir. Aksi durumda; kriz iletişiminin en temel bileşeni olan güven büyük zarar görecek; kriz yönetiminden sorumlu kurumun kriz iletişimi zorlaşarak, halk kuruma, önlemlerine ve kontrol faaliyetlerine şüphe ile yaklaşacaktır. Bu nedenle devletin taraf olduğu ve kriz iletişimini üstlendiği durumlarda; kriz yönetiminden sorumlu kurumunun özel bir planlama çerçevesinde kendi kriz iletişimini başlatması ve sürdürmesi; kriz iletişimi süresince haber kaynağı olarak güvenilirliğini ve etkinliğini sürdürmeyi başarabilmesinde önemli bir etken olarak değerlendirilmektedir. Halkın ve medyanın bilme hakkının kilit rol oynayacağı kriz iletişim sürecinde medya desteğinin sağlanması, kurumun tüm iletişim aşamalarında bilgi üzerinde kontrol sağlaması ve bilgiyi büyük ölçüde yönetebilmesiyle kriz iletişim süreci kolaylaşacaktır.

Salgın hastalıklardan kaynaklanan ve halkın sağlığını tehdit eden bu tür kriz durumlarında; kriz iletişiminin diğer bir önemli bileşeni şeffaflıktır. Şeffaflık; krizden korunmak için bilgi, tavsiye bekleyen halka, bilginin nasıl elde edildiği, kararların nasıl alındığı ve krizin nasıl yönetildiği konusunda bilgi paylaşımına işaret eder. Böylelikle halkın salgın hastalıktan korunabilmesi için alması gereken önlemler ve davranış değişikliğinin kolay benimsenmesi sağlanabilecek, belirsizlik ve bilinmezlik içeren kriz ortamında kriz yönetiminden sorumlu kurum ve yöneticilerinin kriz ile bașa çıkabilmek için çaba gösterdiğinin anlaşılmasına katkı sağlanacaktır. 'Demokratik toplumlarda halkın, kendisine hizmet etmek amaciyla yönetimi verdiği hükümetin halka ne kadar hizmet edebildiğine, halkın yararını ne kadar düşündüğüne ve güvenliğini ne kadar koruyabildiğine dair en önemli sınavını kriz dönemlerinde vermektedir' (Gülgün, 2011: 46). Halkın sağlığının korunması ve güvenliğinin sağlanması önceliği ile doğru bilgi ve tavsiyeleri halk ile paylaşmak asli göreviyle; toplumsal sorumluluk çerçevesinde salgın ve salgın yönetiminin devlete maliyeti gibi ekonomik kaygılar ve politik kaygılar bir yana bırakılarak, kamu hizmetlerinin kesintiye uğramamasına odaklanarak, şeffaf bir kriz iletişimi gerçekleştirilmelidir. Kriz iletişiminde şeffaflık sergilenirken 'bireysel haklar, kamu yararı ve halkın ihtiyacı olacak bilgi arasında denge kurulmalıdır' (Akt. Gülgün, 2011: 52).

Salgınlarda kriz iletişimi gerçekleştirilirken, iletişimin başarısını belirleyecek en önemli etken halktır. $\mathrm{Bu}$ nedenle halkı anlamak, kriz iletişim sürecinde alınacak kararlarda iki yönlü düşünerek halka verilecek mesajların halkın kendisini ve yakınlarını korumak ve güvende olabilmesi için; açık, anlaşılır bir şekilde, teknik ve tıbbi terimlerden sadeleştirerek, ülkedeki demografik, kültürel, geleneksel yapı gibi özellikler dikkate alınarak oluşturulmuş kapsamlı bilgiler çerçevesinde ne yapabileceğini içermelidir. Böylelikle 'koruyucu önlemler hakkında gerçekleştirilecek bir iletişim planlamasıyla halkın kendi sağlığını korumak için sorumluluk almasına yardımcı olunacak' (Gülgün, 2011: 54), tavsiyelerin dikkate alınması mümkün olacaktır. Bu nedenle krizin yönetiminden sorumlu kurum ve yöneticilerinin; kendine güvenen bir şekilde, sükûnetle, konun her noktasına hakim bir tavırla, güven verici bir yaklaşım göstermesi son derece önemlidir. Çünkü kriz zamanlarında sergilenecek yönetsel beceriler, örgütü dağılmaktan kurtaracağ 1 gibi, krizin yarattığı panik ortamını gidererek kriz durumunun en az hasarla atlatılmasına yardımcı olacaktır. Çoğu kamu kuruluşunun varlığı kriz nedeniyle tehdit altında olmasa da; 'devletin bizzat taraf olduğu kriz durumlarında sürdürülen kriz yönetiminin başarısızlı̆̆ı, hükümetlerin düşmesi, kurumun başındaki yönetici ve bürokratların istifası gibi ağır sonuçlara sebebiyet verebilecektir' (Gülgün, 2011: 54). 


\subsection{Kriz İletişim Yönetimi ve Sosyal Medya}

'Enformasyon ve iletişim teknolojileri çağının yaşandığı günümüzde, yaşamın her alanına giren internet, 2000'li yıllarla birlikte neredeyse en etkili iletişim kanalı olarak geniş kitleler tarafından kullanılmaya başlanmıştır' (Yayınoğlu vd., 2007: 132). Enformasyon teknolojisinin zamanla iletişim teknolojisiyle olan yakınlaşması ve bunun günümüzdeki yaygın uygulamalarından birini oluşturan; basit bir anlatımla 'paket anahtarlama yoluyla verileri transfer eden dünya çapında kamuya açık bir erişimi olan birbiriyle bağlantılı bir seri bilgisayar ağları' (Yayınoğlu vd., 2007: 132) olarak tanımlanabilen internetle; alanda dönüşümün hız kesmeden günümüze kadar uzanarak farklı tipte iletişim kanallarının oluşmasına ortam sağlanmıştır. 'İnternetin zaman içindeki dönüşümü kapsamında, 2004 yılından itibaren günlük hayata ikinci nesil internet olarak da bilinen web 2.0 kavramı girmiştir. Web 2.0 teknolojileri ile aynı anlamda kullanılan sosyal medya araçları ve uygulamaları (Facebook, Twitter, YouTube, Linkedln vb.) internetin daha etkileşimli ve katılıma dayalı hale gelmesine yönelik uygun bir ortam yaratmıştır' (Gülaslan, 2018: 1).

İnternetin getirdiği en son yeniliklerden beslenen ve karşılıklı olarak iletişim ve etkileşim tesis etmeye yönelik bir vasıta olarak tanımlanabilen sosyal medyanın özelliklerine her geçen gün yenilikler eklemesi nedeniyle literatürde farklı tanımlamalarına rastlamak mümkündür. $\mathrm{Bu}$ tanımlamalar içerisinde en yaygın olanlardan biri 'web 2.0'ın teknolojik ve ideolojik temelleri üzerine kurulmuş olan ve kullanıcı bazlı içeriklerin yaratılmasına ve karşılıklı olarak değiştirilmesine imkan tanıyan bir grup internet temelli uygulamalardır' (Kaplan ve Haenlein, 2010: 61) şeklindedir. Sosyal medyanın; 'teknolojiyi, sosyal girişimciliği kelimeler, resimler, videolar ve ses dosyaları ile birleştiren; kullanıcıların birbirleriyle bilgi, görüş ve ilgi alanlarını paylaşarak etkileşim kurmaları için olanak sağlayan çevrimiçi araçlar ve web sitelerini içermekte olan şemsiye bir kavram' (Onat, 2010: 105), 'geleneksel medyanın statik ve tek taraflı iletişim sağlayan yapısından farklı olarak, gelişen internet teknolojilerinin kullanıldığı, dinamik, kullanıcıların içerik oluşturup paylaşabildikleri, etkileşim ve katılım esasına dayalı dijital iletişim ortamları' (Ertaş, 2015: 19), 'web 2.0'ın kullanıcı hizmetine sunulmasıyla birlikte, tek yönlü bilgi paylaşımından, çift taraflı ve eş zamanlı bilgi paylaşımına ulaşıımasını sağlayan medya sistemidir' (Keskin \&Baş, 2015: 51) şeklinde tanımları da yapılmıştır. Sosyal medya ile ilgili yapılan bu tanımlamalar incelendiğinde; ortak özellikler olarak, 'kullanıcıyı merkeze alan yapısıyla beraber, internet ve teknolojinin desteğiyle sosyal medyanın insanlar arasındaki işbirliğinin, etkileşimin ve paylaşımın tesis edilmesine yönelik önemli bir araç olduğu' (Gülaslan, 2018: 13) anlaşılmaktadır.

Mobil iletişim teknolojilerindeki yenilikler, günümüzde sosyal medyanın en temel iletişim kanallarından birisi haline gelmesinde önemli rol oynamaktadır. Bu çerçevede sosyal medya bugün sahip olduğu özellikler ve toplumda yarattığ 1 etkiler sayesinde, insanların sadece vakit geçirdikleri bir ortam olmaktan öte; kişisel ve kurumsal kültürün önemli bir parçası haline dönüşmüştür. 'İlk ortaya çıktığında sadece bireysel kullanımların ağırlıkta olduğu sosyal medya platformları, günümüzde kamu kurumları ve aktörleri tarafından da farklı bir iletişim ve hizmet sunum şekli sağlayan ve karşı1lıklı etkileşime yeni bir boyut kazandıran önemli bir platform olarak görülmektedir' (Gülaslan, 2018: 1). Kamu kurumları ve aktörleri de zaman ve mekandan bağımsız olarak bu mecralarda yer alarak, vatandaşlarla daha fazla etkileşim içerisine girebilme gayreti içerisindedir.

'Halkın da yoğun olarak içerisinde yer aldığı ve aktif katılım sağladığı Facebook, Twitter ve YouTube vb. sosyal medya platformları, kamu kurumları ve aktörlerine; hedef kitlelerine en kısa yoldan ulaşmak ve kurumsal mesajlarını, faaliyetlerini aktarmada, hizmet sunmada, onlardan geribildirim almada ve kamuoyunda tartışılan konuların ne olduğu konusunda fikir sahibi olmada az maliyetli ve pratik firsatlar sunmaktadır' (Gülaslan, 2018: 2). Bu çerçevede; günümüz dünyasında kriz iletişim yönetimini de sosyal medya kavramından bağımsız düşünmek mümkün değildir.

İnternetin ortaya çıkması kriz iletişiminde de belirli değişiklikler ve gelişmeler yaşanmasına yol açmıştır. Hem krizlerin başladığı, yayıldığı, hem de önlendiği alanlar olarak sosyal medya, kriz 
iletişiminde merkezi bir konuma yükselmiştir. Sadece internet tabanlı krizler değil, geleneksel krizlerin kontrol edilmesinde de kurum ve kuruluşlara önemli katkılar sağlamaktadır. Bu bağlamda internet ve sosyal medya gibi yeni iletişim teknolojilerinin kişiler ve kurumlar tarafından başarılı bir şekilde kullanılmasıyla kriz iletişiminde güçlü iletişim araçlarına dönüşebilmektedir. Kurumlar, internet ve sosyal medya platformlarını kriz iletişiminde kullanarak; en temelde güncel bilgiyi en kısa zamanda olabildiğince fazla sayıda kişiye ulaştırabilme olanağına sahip olmaktadır. Böylelikle, kurumlar, krizle ilgili anlatmak istediklerini kamuoyuna iletebilme olanağını elde etmiş olurlar. Günümüzde yaşanan krizlerde sosyal medya, doğru olmayan bilgilerin yayılması açısından da büyük riskler taşımaktadır. Ancak olumsuz özelliklerine karşın sosyal medyanın yaşanan krizlerde çözüm odakl1 örnekler sunduğu da bir gerçektir.

Kriz dönemlerinde, krizden sorumlu kurum ve yöneticilerinin bilgi paylaşımı hayati önemdedir. Sosyal medya araçları sayesinde, bilgi paylaşımının çok hızlı ve kolay bir şekilde gerçekleştirilmesi mümkün olmaktadır. Bu çerçevede, bu araçların etkin kullanımı; tüm sosyal paydaşların ve medyanın gerektiği biçimde bilgilendirilerek panik ortamının da ortadan kaldırılmasına yardımcı olmaktadır. Kriz dönemlerinde doğru bilgi paylaşımının önemi çerçevesinde, bilginin her an güncellenebildiği sosyal medya ortamları halk ve medyanın tüm sorularına cevap verebilme anlamında önemli katkılar sağlamaktadır. Günümüzde kriz iletişiminin en önemli ayağı haline gelen sosyal medyada; son dakika güncellemelerini diğer sosyal medya araçlarına kıyasla çok kolaylaştıran mikrobloglar arasında yer alan Twitter'ın, kriz iletişiminin en önemli aracı olduğu söylenebilir.

Araştırma kapsamında ele alınan ve sosyal medya araç ve uygulamaları arasında 'dünyadaki en güçlü çevirimiçi topluluklardan biri olarak kabul edilen Twitter ile insanlar arasındaki etkileşim diğer sosyal medya uygulamalarından farklı olarak herhangi bir arkadaşlık onayı gerektirmeksizin takip edilen (following) ve takipçi (follower) ekseninde gerçekleşmekte, yaratılan içerikler haricinde diğer kullanıcılar tarafından oluşturulan içeriklerin de tekrar yayımına (retweet) imkân tanınmaktadır'(Gülaslan, 2018: 47). 'Twitter, kullanıcıların ilgiye değer konularda en yeni bilgilere ulaşmayı mümkün kılan gerçek zamanlı bir bilgi ağıdır’ (Aslan, 2015: 18).

Kamu kurumları ve aktörleri tarafindan da kullanılan en popüler mikroblog sitesi olarak kabul edilen ve en temel olarak, 'kamu kurumlarının kurumsal internet siteleri üzerinden dişarıya ilettikleri mesajların farklı bir iletişim kanalı ile aktarımını sağlayan Twitter, bu kapsamda, kamu kurumları tarafından Twitter güncellemeleri (updates), başlıca basın açıklamalarının ve çeşitli duyuruların yayımlanması maksadıyla da kullanılmaktadır' (Gülaslan, 2018: 47). Bu özellikleri çerçevesinde ve etkili olarak kullanıldığında; hızlı haberleşmenin önem arzettiği, bilgi paylaşımının hayati önemde olduğu kriz dönemlerinde kamu kurumları ve yöneticileri tarafından paylaşılan içeriklerin kitleler arasında daha önce hiç olmadığı kadar hızlı bir şekilde bir çı̆̆ gibi büyüyerek yayılması, sınırsız sayıda insana ulaşabilmesi ve etkileşim sağlaması bakımından önemli avantajlar sağlamaktadır. Krizin yönetilmesinden sorumlu kurumun üst düzey yöneticilerinin de tanınmış kişiler olması ve bu kişilerin sosyal medya hesaplarının genellikle kurumun sosyal medya hesaplarına göre daha fazla kişi tarafından takip edilmesi, kriz dönemindeki paylaşımlarının kurumsal amaçların gerçekleştirilmesinde de büyük katkılar sağladığı bilinmektedir. Çünkü özellikle devletin taraf olduğu kriz dönemlerinde halk devlet yöneticilerinin yetkin kararlar aldığını görmek ister.

Başarılı bir kriz iletişim yönetimi, halkın ve tüm paydaşların medya seçimine dair planlı seçimler yapılmasıyla sağlıklı bir şekilde sürdürülebilir. Günümüzde internet ve web tabanlı son teknolojilerin adeta odak noktası haline gelen sosyal medya ve özellikle de Twitter gibi mikrobloglarda geleneksel iletişim kanallarına göre oldukça hızlı bir iletişim sağlanması ve ihtiyaçların hızla tanımlanarak, bu doğrultuda hareket edilmesi mümkün olabilmektedir. İnternet ve 
sosyal medya araçlarının yaygın kullanımının; geleneksel iletişim sürecinde kullanılan araç ve ortamların etkisini arttıran ve destekleyen bir özellik taşıdığı da bilinmektedir.

\section{Covid-19 Salgınının Yönetilmesinde Sosyal Medya Kullanımı: Sağlık Bakanı Fahrettin Koca'nın Resmi Twitter Hesabı Üzerine Bir Analiz}

\subsection{Yöntem}

$\mathrm{Bu}$ çalışmanın temel amacı, etkinliğini her geçen gün arttıran sosyal medyanın en önemli platformlarından biri olan Twitter'ın kriz iletişim yönetimindeki rolü, yakın tarihimizin en büyük krizi olan Covid-19 pandemisi sürecinde T.C. Sağlık Bakanı Fahrettin Koca'nın Twitter paylaşımları üzerinden incelenecektir. Tüm dünya ülkelerini etkisi altına alan ve küresel düzeyde ölümlere yol açan Covid-19 salgınının yarattığı kriz ortamında çalışmanın evrenini oluşturan birçok devletin kriz iletişim faaliyetlerinde; sağladığ 1 olanaklar nedeniyle sosyal medya mecralarından etkin olarak faydalanılmaktadır. Türkiye'de kriz iletişim süreci, krizin tarafı devleti temsilen ülkenin sağlık mevzuatı ve uygulamalarında sorumlu Sağlık Bakanlığı tarafından gerçekleştirilmiştir. Bu çerçevede çalışmanın örneklemini; bu süreçte kriz iletişim yönetiminin sorumlusu ve kriz iletişiminin yürütücüsü olarak Sağlık Bakanlığının, sosyal medya hesaplarından Twitter'ı aktif olarak kullandığ1 Bakan Fahrettin Koca'nın resmi twitter hesabında yer alan paylaşımlar oluşturmaktadır. Çalışmada içerik analizi yöntemi kullanılmıştır. Nitel araştırma yöntemlerinden bir olan ve 'iletişimin yazılı, açık içeriğinin nesnel, sistematik ve nicel tanımlarını yapan bir araştırma tekniği' (Berelson, 1971: 18) olarak tanımlanan içerik analizi yöntemi ile gerçekleştirilen bu çalışmada; Türkiye'de ilk vakanın tespit edildiğinin resmi olarak açıklandığ 11 Mart 2020 ve 25 Mart 2020 tarihlerini de içine alan on beş günlük süre analiz edilmiştir. Çalışma, Türkiye'de Covid-19 salgınının ortaya çıkması ve ilk vakanın tespit edildiği 11 Mart 2020 tarihinden itibaren hastalığın kuluçka dönemi olarak belirlenen 14 günlük süreçle beraber toplam 15 günlük zaman dilimi ile sınırlandırılmıştır. Bu süre içinde, Sağlık Bakanı Fahrettin Koca'nın resmi twitter hesabı üzerinden kriz iletişimi bağlamında gönderilen iletiler, SPSS programı kullanılarak analiz edilmiş; veriler tablolaştırılmıştır. Araştırma kapsamında; belirlenen tarihler arasında, takipçi sayısı 5.6 milyon olan Sağlık Bakanı Fahrettin Koca'nın resmi twitter hesab1 @drfahrettinkoca üzerinden, kriz yönetimi iletişimi ekseninde paylaşılan özgün tweetler incelenmiş; analiz sonucu ortaya çıkan bulgular, kriz yönetimi iletişimi ekseninde niteliksel bir yoruma tabi tutulmuştur. Devletin taraf olduğu bir halk sağlığı krizi olan Covid-19 salgını sürecinde T.C. Sağlık Bakanı Fahrettin Koca'nın resmi twitter hesabı üzerinden yürüttüğü kriz iletişim faaliyetleri; tweet paylaşımı, tweet paylaşım türü, tweet içeriği ve görsel tweet içerikleri tablolarda belirtilen alt başlıklarıyla, çalışmada ele alınan literatür ışığında değerlendirilerek, kriz iletişimi sürecinde sosyal medyanın önemi ve etkisi, nasıl kullanıldığı, etkin kullanıldığ taktirde kriz iletişimine nasıl katkı sağladığı ortaya konmuştur.

\subsection{Araştırmanın Bulguları}

Çalışmada bu başlık altında; Türkiye'de Covid-19 salgınının neden olduğu kriz döneminde; kriz iletişim faaliyetlerini özellikle sosyal medya mecrası Twitter'ın desteği ile yürüttüğü görülen Sağlık Bakanı Fahrettin Koca'nın, 11.03.2020 ve 25.03.2020 tarihleri arasında resmi twitter hesabı üzerinden paylaşmış olduğu özgün tweetlerin analizi yapılmış; elde edilen veriler tablolaştırılarak yorumlanmıştır. Elde edilen veriler aşağıdaki tablolarda belirtilmiştir.

Tablo 1: Sağlık Bakanı Fahrettin Koca'nın Resmi Twitter Hesabında 11.03.2020-25.03.2020

Tarihleri Arasındaki Tweet Paylaşımı

\begin{tabular}{|l|l|l|}
\hline Tweet Paylaşımı & Günlük Ortalama Paylaşım & \multirow{2}{*}{ Toplam Gün Sayıs1 } \\
\cline { 2 - 2 } (11 Mart-25 Mart 2020) & 7 & 15 \\
\hline Toplam Paylaşım & 96 & \\
\hline
\end{tabular}

Turkish Studies, 15(6) 
Elde edilen verilere göre; Tablo 1'de görüleceği üzere Sağl1k Bakanı Fahrettin Koca, resmi twitter hesabından 11 Mart 2020-25 Mart 2020 tarihleri arasında bu tarihleri de içine alan 15 günlük süre içinde, halk ile iletişimi sağlamak ve halkı bilgilendirmek için toplam 96 tweet paylaşmıştır. $\mathrm{Bu}$ süre içinde günde ortalama 7 tweet paylaşmıştır. 'Kurumlar ya da temsilcileri tarafından başarılı bir şekilde kullanılması durumunda kriz iletişiminde etkili bir iletişim aracına dönüşen (Çetin \& Emre, 2016: 57) Twitter'da, Türkiye'de yeni tip koronavirüs salgının başladığının ve ilk vakanın tespit edildiğinin resmi olarak açıklandığı ilk gün olan 11 Mart 2020'den itibaren, Sağlık Bakanı Fahrettin Koca resmi twitter adresinden on beş günlük süreçte toplamda 96 ileti paylaşmıştır. Bakan Koca'nın 15 gün içinde 96 paylaşım yapması, onun kriz iletişiminde sosyal medyayı aktif biçimde kullandığını göstermesi açısından son derece önemlidir. Günümüzde özellikle sosyal medyanın yaygın kullanımına bağlı olarak, hangi konuda olursa olsun doğruluğu kesinleșmemiș birçok bilginin saniyeler içerisinde milyonlarca kişiye ulaşabildiği bilinmektedir. Bu çerçevede, kriz dönemlerinde ortaya atılan birçok iddia önüne geçilmediği taktirde çığ gibi büyüyerek yayılabilmekte, yayılan bu bilgiler zamanla doğru kabul edilerek kriz için aşılması güç sorunları doğurabilmekte ve kriz yönetimini zorlaştırmaktadır.

Araştırmada analiz edilen tarih aralığında dezenformasyona karşı uyarı niteliği taşıyan paylaşımlar da yapan Bakan Fahrettin Koca bu bağlamda dikkat çeken ilk paylaşımını 14 ve 15 Mart'ta Umreden dönen vatandaşlarımız için yapmıştır. Basında ve sosyal medyada Umreden dönen vatandaşlara yönelik tedbir alınmadığ 1 yönünde yapılan haberlerin, sosyal medyada paylaşılan tweetlerin gerçeği yansıtmadığını belirtmek için bu konuya ilişkin 2 günde toplam 3 tweet atmıştır. Bakan Koca Umreden dönen yolcuların 14 gün kuralına uymaları gerektiğini anlatan ilk paylaşımından sonra diğer iki tweetinde de bu yolcuların Ankara ve Konya'da öğrenci yurtlarında karantinaya alındığını ve şüpheli olanlara test yapıldığını açıklamıştır. En yetkili kişi olan Bakan Koca'nın bu açıklamaları yapması dezenformasyonun önüne geçebilmede etkili bir kriz yönetimi hamlesi olmuştur. Bu çerçevede Sağlık Bakanı Fahrettin Koca; halkı paniğe ve strese sürükleyecek, kriz için aşılması güç sorunları doğuracak bu haberleri yoğun paylaşım yaparak twitter hesabı üzerinden yalanlamış; halkın en doğru bilgiye resmi kanallardan ulaşması gerektiği mesajını vermiştir.

Bakan Koca, 16 Mart tarihinde de benzeri bir bilgi kirliliğinin önüne geçmek için paylaşım yapmıştır. Whatsapp ve sosyal medyada 'Gizli Belge' olarak yayınlanan belgenin fotoğrafını paylaşan Koca, bunun 'gerçek dişı' olduğunu belirterek şu paylaşımı yapmıştır:

‘Sosyal medya ve Whatapp'tan yayılan “GIZZLI” belge GERÇEK DIŞIDIR. Panik yaratacağ bilinerek UYDURULMUŞTUR. Güven kaybına yol açarak, 82 milyonun zaafa düşmesini amaçlayanlar var. Hassasiyetinizle oynayanlar var. Şans tanımayın. DOĞRU HABER, RESMEN YAPILAN AÇIKLAMADIR.'

Görüldüğü üzere, hızla yayılan dezenformasyonun önüne geçebilmek için Sağlık Bakanı Fahrettin Koca twitter hesabı üzerinden yaptığı yoğun paylaşımlarla bu bilgileri yalanlamıştır. Böylelikle halkın bilgi alma hakkı çerçevesinde; halkın kendini ve yakınlarını koruyabilmesi için bilgiye ve tavsiyeye olan ihtiyacının en üst seviyeye çıktığı, halkın sağlı̆̆ını ve iyilik halini tehdit eden Covid-19 salgını sürecinde, halkta güven kaybı ve paniğe yol açabilecek bilgi kirliliğine karşı twitter paylaşımlarıyla uyarı yapan Bakan Koca, halkın en doğru bilgiye Sağlık Bakanlığı aracılığıyla ulaşmasını sağlamıştır. Birinci ağızdan en doğru bilgilerin verilmesi ile, kamuoyunda oluşabilecek şüphe ve olumsuz algıların hızlı bir şekilde engellenmesi amaçlanmıştır. Kriz sırasında en yetkili makam olarak Sağlık Bakanı Fahrettin Koca'nın resmi twitter hesabından yaptığı bu paylaşımlar Sağlık Bakanlığı'nın itibarı açısından da son derece önemli adımlar olmuştur.

Kriz iletişiminde en önemli unsurların başında medya gelir. Bu bağlamda; kriz yönetiminde medya desteğinin sağlanması, kurumun tüm iletişim aşamalarında bilgi üzerinde kontrol sağlaması ve bilgiyi büyük ölçüde yönetebilmesi kriz iletişim sürecine son derece önemli katkılar sağlayacak, 
kriz iletişim sürecini kolaylaştıracaktır. Bu çerçevede; halkın ve medyanın bilme hakkının kilit rol oynayacağ 1 kriz iletişim sürecinde Sağlık Bakanı Fahrettin Koca'nın resmi twitter hesabı üzerinden 12 Mart tarihinde yaptığı 'MEDYA, BU ULUSAL MÜCADELENIN ANA AKTÖRLERINDEN BİRIDİR. Biz süreci bugüne dek birlikte yürüttük. Şeffaf davrandık, destek kazandık. İş birliğimiz aynı ilkelerle devam edecek. Güvenilir bilginin aracı saygın medyadır. Medyanın saygın mensuplarıdır. Sizlersiniz.' şeklindeki paylaşımı medyanın desteğinin sağlanması yönünde önemli mesajları içermiştir. Dünyayı etkisi altına alan Covid-19 salgını ile mücadeleyi ulusal mücadele olarak tanımlayan Bakan Koca, bu mücadeledeki en büyük işbirlikçilerinden birinin medya olduğunu belirterek; twitter üzerinden yaptığı paylaşımla bu beyanı daha dikkat çekici hale getirmek için büyük harfler kullanmıştır. Medya ve mensuplarını saygın olarak nitelendiren Bakan Koca, kriz iletişimindeki önemli bileşenlerden biri olan şeffaflık gereği yapılan bilgilendirmelerde medyanın desteğinin sağlanması yönünde önemli mesajlar vererek; medyanın doğru bir şekilde bilgilendirilmesi ile oluşabilecek bilgi kirliliğinin de önüne geçebilme noktasında kamuoyunda sürece yönelik oluşabilecek olumsuz algının da önüne geçmeye çalışmıştır. Bu çerçevede twitter üzerinden yaptığı sistemli paylaşımlar, kriz iletişimi sürecinde haber kaynağı olarak güvenilirliğini ve etkinliğini sürdürebilmesi açısından önemli bir etken olarak değerlendirilmektedir.

Sağlık Bakanlığı tarafından başlatılan sağlık kampanyasına da destek veren Bakan Koca, 24 ve 25 Mart tarihlerinde ise 'Hayat eve sığar' etiketiyle piyanist Fazıl Say, oyuncu Burak Özçivit, Fahriye Evcen ve müzisyen Mazhar Alanson'un resimlerinin bulunduğu Sağlık Bakanlığı tarafından hazırlanan afişleri paylaşmıştır. Bu paylaşımlarla; hem vatandaşların 'evde kal' yönündeki çağrılara dikkatinin çekilmesi, hem de evde de hayatın devam edeceği vurgulanarak; vatandaşların bu sürece uyum sağlamaları yönünde motive edilmeleri amaçlamıştır. Afiş̧lerde ünlü isimlerin kullanılması ise afişlerin halk açısından daha dikkat çekici olmasını sağlamıştır.

İncelenen tarih aralığında Bakan Koca'nın diğer önemli bir paylaşımı ise; sağlık çalışanlarına yönelik başlatılan, her akşam saat 21.00'deki 'sağlık çalışanlarımıza minnettarlığımızı göstermek için yapılan alkışlama' kampanyası olmuştur. Cumhurbaşkanı Recep Tayyip Erdoğan olmak üzere toplumun büyük bir kesiminin destek verdiği bu kampanya, salgın sürecinde cephenin en önünde toplum sağlığı için çalışan sağlıkçılara moral desteği vermek üzere yürütülen önemli bir kampanya olmuştur. Bakan Koca, bu kampanya ile ilgili farkındalık yaratmak için ardı ardına paylaşımlar yapmıştır. 19 Mart'ta başlayan kampanyanın üç gün süreceğini Bakan Koca hesabından şu cümlelerle açıklamıştır: 'Yarın, ertesi gün aynı saatte minnettarlığımızın sesi tekrar duyulsun. ÜST ÜSTE ÜÇ GÜN ALKIŞLAYALIM’

Erkek'in (2016:143) belirttiği gibi kamu hizmetlerinin sunumunda katılım, halk1 bilgilendirme, şeffaflık ve hesap verebilirlik gibi yönetişim ilkelerinin daha da önem kazandığ kriz dönemlerinde; Sağlık Bakanı Fahrettin Koca, günde ortalama 7 tweet paylaşmıştır. Türkiye'de ilk vakanın tespit edildiğinin resmi olarak açıklandığı 11 Mart'tan itibaren 15 günlük bu süreçte; bilgilendirme, tedbir, öneriler ve güncel vaka sayılarının en yetkili makamdan vatandaşla paylaşılması kriz sürecinin etkin bir biçimde yönetilme çabası içinde olunduğuna dair önemli bir gösterge olmuştur.

Tablo 2: Sağlık Bakanı Fahrettin Koca'nın Resmi Twitter Hesabında 11.03.2020-25.03.2020

Tarihleri Arasındaki Tweet Paylaşım Türü

\begin{tabular}{|l|l|l|}
\hline İleti Türü & Adet/Sıklık & Yüzde (\%) \\
\hline Mesaj & 32 & 33,3 \\
\hline Fotoğraf & 22 & 23 \\
\hline Video & 42 & 43,7 \\
\hline Toplam & 96 & 100,0 \\
\hline
\end{tabular}


Sağlık Bakanı Fahrettin Koca'nın araştırma kapsamında belirlenen tarih aralığında resmi twitter hesabından yaptı̆ğ tweet paylaşımlarının türüne göre verilerin yer aldığı Tablo 2'de; toplam 96 paylaşımın; \%33,3'lük kısmının mesaj, \%23'lük kısmının fotoğraf ve \%43,7'lik kısmını da videoların oluşturduğu görülmektedir. Paylaşımların 22'sinin fotoğraflar eşliğinde verilmesi, verilen mesajların daha etkili ve ilgi çekici hale getirilerek kriz iletişim sürecinde katkı sağlaması açısından son derece önemlidir. Görselliğin yanı sıra işitsel açıdan da son derece etkili olan, önemli avantajlar sağlayan video kullanımı, fotoğraflara oranla daha çok tercih edilerek 42 tane videolu ileti kullanılmıştır. Görsel öğelerin yer almadığı, salt mesajların verildiği ileti sayısı ise 32 'dir.

Araştırma kapsamında incelenen tarih aralığında bu çerçevede ele alınabilecek; kamuoyunu bilgilendirmek amacıyla yurtdışından gelenler için uygulanması gereken 14 gün kuralını toplamda 6 tweet ile paylaşan Bakan Koca, tweet paylaşım türü olarak değerlendirildiğinde; bu kuralları hem video hem de fotoğraf formatında yayınladığ 1 görülmektedir. Bu bağlamda, verilmek istenen mesajların farklı formatlardaki paylaşımına olanak sağlayan twitter üzerinden gerçekleştirdiği paylaşımlar Bakan Fahrettin Koca'nın kriz iletişiminde, verilmek istenen mesajların etkili olmasında önemli bir araç olarak kullanıldığını da göstermektedir. Bakan Koca'nın, vaka sayılarını ve salgına yönelik güncel bilgileri hem yazılı hem de video şeklinde paylaşması ise dikkat çekici bir unsurdur. Özellikle Meclis'teki konuşmasını ve milletvekillerin sorularını yanıtlayan videoları yayınlayarak topluma hesap verilebilir ve şeffaf bir yönetim şekli benimsediğini de göstermesi açısından son derece önemlidir. Bu noktada da sosyal medyayı etkin biçimde kullanmıştır.

Tablo 3: Sağlık Bakanı Fahrettin Koca'nın Resmi Twitter Hesabında 11.03.2020-25.03.2020 Tarihleri Arasında Paylaştığı Tweet İçeriği

\begin{tabular}{|l|l|l|}
\hline Paylaşılan İletinin İçeriği & Adet/Sıklık & Yüzde (\%100) \\
\hline Tedbir/Önlem İçerikli Atılan Tweetler & 26 & 27 \\
\hline $\begin{array}{l}\text { Bilgilendirme Amacıyla Atılan Tweetler/ } \\
\text { Güncel Bilgilendirme }\end{array}$ & 37 & 38,5 \\
\hline Sağlık Kampanyası Karşı Uyarı ve & 23 & 24 \\
\hline $\begin{array}{l}\text { Dezenformasyona Kana } \\
\text { Bilgilendirme Amacıyla Atılan Tweetler }\end{array}$ & 4 & 4,2 \\
\hline $\begin{array}{l}\text { Covid-19 Salgını Dışındaki Konularla İlgili } \\
\text { Atılan Tweetler }\end{array}$ & 6 & 6,3 \\
\hline Toplam & 96 & 100 \\
\hline
\end{tabular}

Sağlık Bakanı Fahrettin Koca'nın araştırma kapsamında belirlenen tarih aralığında resmi twitter hesabından paylaştığı tweet içeriklerine ilişkin verilerin yer aldığg Tablo 3'de; paylaşılan 96 iletinin \%38,5'ni salgına ilişkin bilgilendirme amacıyla atılan tweetler ve güncel bilgilendirmeler oluşturmuştur. Paylaşılan iletilerin \%27'sini tedbir/önlem içerikli atılan tweetler oluşturmuştur. Bakan Koca paylaşımlarının \%24'ünü ise salgınla mücadelenin en kritik döneminde Bakanlık tarafından hazırlanan sağlık kampanyasına dair yapmıştır. Bakan Koca'nın paylaşımlarının $\% 4,2$ 'sini dezenformasyona karşı uyarı ve bilgilendirme amacıyla atılan tweetler ve \%6,3'ünü de Covid-19 salgını dışındaki konularla ilgili atılan tweetler oluşturmuştur.

Kriz dönemlerinde, krizden sorumlu kurum ve yöneticilerinin bilgi paylaşımı hayati önemdedir. Sosyal medya araçları sayesinde, bilgi paylaşımının çok hızlı ve kolay bir şekilde gerçekleştirilmesi mümkün olmaktadır. Araştırma kapsamında incelenen tarih aralığında kriz iletişimi sürecinde Sağlık Bakanı Fahrettin Koca resmi twitter hesabı üzerinden yaptığı paylaşımlarla her gün düzenli olarak test ve vaka sayıları hakkında kamuoyunu bilgilendirmiş; alınan tedbirleri açıklamıştır. Devletin asıl amacının salgını tıbbi olarak kontrol etmek, yayılmasını önlemek ve oluşacak güven çaresizliğini ortadan kaldırmak olacağı Covid-19 salgını krizinde; kriz iletişiminde 
en önemli bileşenlerin başında gelen güvenin oluşturulmasında, halkın açık ve samimi bir şekilde bilgilendirilmesi kilit rol oynar. Böylelikle güvene bağlı olarak halk arasında daha az panik gelişmesine yardımcı olunur, alınan tedbirlerin ve uyulması gereken kuralların şüpheye yer bırakmaksızın uygulanması noktasında önemli katkılar sağlar. Bu bağlamda, Bakan Koca'nın 11 Mart tarihinde paylaştığı tweet kriz yönetimi sürecine dair önemli ipuçları taşımaktadır:

'Hızlı yayılan bulaşıcı hastalıklara karşı başarıyı 4 şey tesis eder. Güçlü tedbir, süratli müdahale, yaygın sağlık altyapısı, güven verici bilgilendirme. Bu 4'üne de sahibiz. Tedbirde birlikteyiz. Mücadeleyi birlikte vereceğiz. HER ÖNEMLİ OLAYI SİZE TITTIZLIKKLE BİLDIRECEĞİZ.'

Bakan Koca bu paylaşımı ile tedbirler ve müdahaleye verdikleri önemi vurgularken bir yandan da panik ortamını önleyebilmek için sağlık sisteminin sağlam alt yapısı olduğuna işaret etmiştir. Paylaşımda kullanılan güven verici bilgilendirme ifadesi ile Bakanlık olarak yapılan bilgilendirmelerin doğruluğunun altını çizerek oluşabilecek olumsuz algıların önüne geçmeyi amaçlamıştır. Kriz yönetiminde şeffaflık ilkesine verilen ehemmiyeti vurgulamak için 'her önemli olayı size titizlikle bildireceğiz' cümlesini büyük harflerle yazarak paylaşması da dikkat çekicidir. Belirsizlik ve bilinmezlik içeren kriz ortamında Bakan Koca'nın bu kapsamdaki paylaşımları kriz yönetiminden sorumlu kurum ve yöneticilerinin kriz ile başa çıkabilmek için çaba gösterdiğinin anlaşılmasına katkı sağladığı gibi, halkın kendi sağlığını korumak için sorumluluk almasına yardımcı olmuştur.

Bu süreçte Bakan Koca'nın twitter paylaşımlarında kullandığı dil de oldukça önemlidir. 'Tedbirde birlikteyiz. Mücadeleyi birlikte vereceğiz.' gibi ifadeler kullanarak sorunların üstesinden birlikte gelineceğine vurgu yapan Koca, kullandığı üslupla kriz iletişim sürecine önemli katkılar sağlamış, halkın her koşulda yanında olunduğunun mesajı verilmiştir. Bu süre içinde yaptığı paylaşımlar ve paylaşımlarda kullandığı dil, Sağlık Bakanı Fahrettin Koca'nın imajını da olumlu yönde etkilemiş, devleti temsilen kuruma olan güvenin oluşmasına ya da pekişmesine de olumlu bir etkisi olduğunu göstermiştir.

Tablo 4: Sağlık Bakanı Fahrettin Koca'nın Resmi Twitter Hesabında 11.03.2020-25.03.2020 Tarihleri Arasında Paylaştığı Görsel Tweet İçeriği

\begin{tabular}{|l|ll|lr|l|}
\hline \multirow{2}{*}{ Görsel İletinin Türü } & \multicolumn{3}{l|}{ Görsel İletinin İçerĭgi } & \multicolumn{3}{l|}{} \\
\cline { 2 - 5 } & $\begin{array}{l}\text { Covid-19 Salgını İle } \\
\text { İlgili }\end{array}$ & $\begin{array}{l}\text { Covid-19 } \\
\text { Dişındaki } \\
\text { İlgili }\end{array}$ & $\begin{array}{r}\text { Salgını } \\
\text { Konularla }\end{array}$ & Toplam \\
\hline Fotoğraf & 19 & 3 & 22 \\
& $\% 86,3$ & $\% 13,7$ & $\% 100$ \\
& $\% 31,1$ & 0 & $\% 34,3$ \\
\hline Video & 42 & - & 42 \\
& $\% 100$ & - & $\% 100$ \\
& $\% 68,9$ & & $\% 65,7$ \\
\hline Toplam & & 3 & 64 \\
& $\% 1$ & $\% 4,7$ & $\% 100$ \\
& $\% 95,3$ & & \\
\hline
\end{tabular}

Sağlık Bakanı Fahrettin Koca'nın araştırma kapsamında belirlenen tarih aralığında resmi twitter hesabından paylaştığı görsel tweet içeriklerine ilişkin verilerin yer aldığı Tablo 4'de; paylaşılan görsel iletinin türüne göre; Covid-19 salgını ile ilgili 19 fotoğraf, Covid-19 salgını 
dışındaki konularla ilgili 3 fotoğraf yer almıştır. Paylaşılan videolar çerçevesinde de; Covid-19 salgını ile ilgili 42 video yer almıştır. Covid-19 salgını dışındaki konularla ilgili video yer almamıştır. Görsel ve işitsel açıdan zengin bir içeriğe sahip olan video paylaşımlarının kriz iletişiminde önemli katkılar sağladığı düşünülmektedir.

Kriz durumlarında, kriz iletişim sürecinde basın toplantıları düzenlemek yapılması gerekenler arasında ilk sırada yer alır. Covid-19 salgını sürecinde incelenen tarih aralı̆̆ında gerçekleştirilen; medyayı ve halkı bilgilendirmek amacıyla sı sık basın toplantıları düzenleyen Bakan Koca, basın toplantılarından kesitleri de video formatında resmi twitter hesabından halka sunmuştur.

\section{Sonuç ve Değerlendirme}

Devletin başarılı ve etkili kriz iletişimi yönetimi; tüm kriz süreçlerinde hızlı, etkili ve güvenilir bilgiler toplayarak; kesintisiz, şeffaf, güvenilir bir yaklaşımla kamuoyuna bunları ulaştırmasıyla mümkün olabilmektedir. Bu çerçevede; günümüzde internet ve web tabanlı son teknolojilerin adeta odak noktası haline gelen sosyal medya ve özellikle de Twitter sağladığı olanaklarla; kişiler ve kurumlar tarafından başarılı bir şekilde kullanılması halinde kriz iletişiminde güçlü iletişim araçlarına dönüşebilmektedir. Türkiye'de Covid-19 salgını sürecinde, Sağlık Bakanı Fahrettin Koca kriz yönetimi ve iletişiminden sorumlu en yetkili isimlerden biri olarak yer almaktadır. Bu çerçevede kriz yönetimi iletişiminin sosyal medya aracılığı ile nasıl yürütüldüğü Fahrettin Koca'nın resmi twitter hesabının incelenmesiyle ortaya konmuştur. Yapılan analiz sonucunda elde edilen bulgular, araştırma kapsamında ele alınan literatür ışığında değerlendirilerek aşağıdaki sonuçlara ulaşılmıştır:

Sağlık Bakanı Fahrettin Koca'nın, resmi twitter hesabından 11 Mart 2020-25 Mart 2020 tarihleri arasında, bu tarihleri de içine alan 15 günlük süre içinde paylaştığı tweetlerin toplam sayısı ve günde ortalama paylaştığı tweetlerin sayısı değerlendirildiği zaman; özellikle Türkiye'de yeni tip koronavirüs salgının başladığının ve ilk vakanın tespit edildiğinin resmi olarak açıklandığı ilk gün olan 11 Mart 2020'den itibaren, Bakan Fahrettin Koca resmi twitter hesabından on beş günlük süreçte toplam 96 ileti paylaşmıştır. Fahrettin Koca'nın 15 gün içinde 96 paylaşım yapması, onun kriz iletişim sürecinde twitteri aktif biçimde kullandığını ve kamuoyunu yoğun olarak bilgilendirdiğini ortaya koymuştur.

Krizin yönetilmesinden sorumlu kurumun üst düzey yöneticilerinin de tanınmış kişiler olması ve bu kişilerin sosyal medya hesaplarının genellikle kurumun sosyal medya hesaplarına göre daha fazla kişi tarafından takip edilmesi, kriz dönemindeki paylaşımlarının kurumsal amaçların gerçekleştirilmesinde büyük katkılar sağladığı bilinmektedir. Çünkü özellikle devletin taraf olduğu kriz dönemlerinde halk devlet yöneticilerinin yetkin kararlar aldığını görmek ister. Bu, kuruma olan güveni güçlendireceği gibi, krizin ilerleyen safhalarında kurumun bilgi üzerindeki kontrolünü de sağlamlaştıracaktır.

Kriz iletişimi sürecinde sosyal medyanın aktif olarak kullanılması, haberleşmenin daha hızlı ve güvenilir olmasının yanı sıra, bir mesajın milyonlara ulaşması da sağlanmış olmaktadır. Hızla yayılma ve bulaşma riski taşıması nedeniyle salgın tehdidinin teyit edilmesiyle birlikte; Bakan Koca'nın resmi açıklamaları twitter hesabından hemen duyurması, tehdidin büyümesi ve olası can kayıplarının önlenmesi, hastalığı belli bir bölgede kontrol altında alabilmek ve güven çaresizliğini ortadan kaldırabilmek açısından önemli bir adım olmuştur. Çünkü halkın sağlığını ve iyilik halini tehdit eden kriz durumlarında, halk kendini ve yakınlarını koruyabilmek için bilgiye ve tavsiyeye ihtiyaç duyar ve bu ihtiyaç olağan dönemlerden farklı olarak en üst seviyeye ulaşır. Bakan Koca'nın incelenen tarih aralığında twitter üzerinden yaptığı paylaşımlarla, halk ve medya en kısa sürede bilgilendirilmiş; halkın kendisinin ve ailesinin sağlı̆ını etkileyecek bilgiye ulaşma hakkının da gerçekleştirilmesi sağlanmıştır. Halkın ve medyanın bilme hakkının kilit rol oynayacağı kriz iletişim sürecinde böylelikle, medya desteğinin sağlanması, kurumun tüm iletişim aşamalarında bilgi 
üzerinde kontrol sağlaması ve bilgiyi büyük ölçüde yönetebilmesiyle kriz iletişim sürecine katk1 sağlanmıştır.

Covid-19 salgını sürecinde, Bakan Koca'nın resmi twitter hesabı üzerinden kriz iletişimini başlatması ve sürdürmesinin; kriz iletişimi süresince haber kaynă̆1 olarak güvenilirliğini ve etkinliğini sürdürmeyi başarabilmesinde önemli bir etkisi olmuştur. Bu çerçevede, incelenen tarih aralığında Bakan Koca'nın paylaştığı tweet içerikleri ile ilgili yapılan değerlendirmede; spekülasyonlar ve provokasyonlara (14 Mart'ta Alo 184 hattıyla ilgili, 15 Mart'ta Umreden gelenlerin karantinaya alınmadıkları yönündeki iddialarla ilgili, 16 Mart’ta Sağlık Bakanlığı'na atfedilen 'gizli belge' iddiasıyla ilgili) karşı bilgilendirici içerikler paylaşılarak gerekli bilgilendirmeler yapıldığı görülmektedir. Bakan Koca'nın, dezenformasyona karşı uyarı ve bilgilendirme amaciyla attığı tweetler, halk ve medyanın birinci ağızdan bilgilendirilerek, halk1 paniğe ve strese sürükleyecek, krizin daha da büyümesine yol açacak haberlerin doğru bilgilerle düzeltilerek gerçek dışılığının anlatılması için de kullanılmıştır. Böylelikle halk ve medya en doğru bilgiye resmi kanallardan ulaşmalıdır mesajı verilmiştir.

Kriz iletişiminin en önemli bileşenlerinden bir diğeri olan şeffaflık ilkesi gereğince; incelenen tarih aralığında krizden korunmak için bilgi ve tavsiye bekleyen halka yönelik olarak, toplumun bilgilendirilmesi noktasında öğretici, akılda kalıcı ve duygusal bir sosyal medya dili kullanılarak atılan tweetlerin; halkın salgın hastalıktan korunabilmesi için alması gereken tedbir ve önlemler üzerinde odaklandığı görülmektedir. İlk vaka tespitinden sonra virüse karşı etkili bir ilacın olmadığı gerçeği hatırlatılarak; virüsle mücadelede en etkili yöntemin, virüsün bulaşmasını önlemek olduğunun altı çizilmiştir. '14 Kural' hatırlatılmış, vatandaşlar sürekli olarak tedbir amaçlı paylaşımlarla bilgilendirilmiştir. Tedbir/Önlem içerikli atılan tweetler çeşitli videolar, akılda kalıcı görseller, fotoğraflar kullanılarak hazırlanmış ve paylaşılmıştır. İncelenen tarih aralığında Bakan Koca'nın paylaşımlarında yer alan görsel tweet içeriği değerlendirmesinde; toplumsal gerginliği azaltacak ve motivasyon sağlayacak video formatında hazırlanmış paylaşımların sıklıkla kullanıldığı görülmektedir.

Salgınlarda kriz iletişimi gerçekleştirilirken, iletişimin başarısını belirleyecek en önemli etken halktır. $\mathrm{Bu}$ nedenle halkı anlamak, kriz iletişim sürecinde alınacak kararlarda iki yönlü düşünerek halka verilecek mesajların halkın kendisini ve yakınlarını korumak ve güvende olabilmesi için; açık, anlaşılır bir şekilde, teknik ve tıbbi terimlerden sadeleştirerek, ülkedeki demografik, kültürel, geleneksel yapı gibi özellikler dikkate alınarak oluşturulmuş kapsamlı bilgiler çerçevesinde ne yapabileceğini içermelidir. Böylelikle koruyucu önlemler hakkında gerçekleştirilecek bir iletişim planlamasıyla halkın kendi sağlığını korumak için sorumluluk almasına yardımcı olunacak, kriz yönetiminden sorumlu kurum ve yöneticilerinin tavsiyelerinin dinlenmesi mümkün olacaktır. $\mathrm{Bu}$ çerçevede Bakan Koca'nın incelenen tarih aralığındaki twitter paylaşımlarında birlik mesajı ön plana çıkarılarak, virüsle mücadelenin tek taraflı yürütülemeyeceğinin de altı çizilmiştir.

Diğer dünya ülkelerine kıyasla Türkiye'de ilk koronavirüs vakasının daha geç görülmesi nedeniyle, koronavirüs salgın kriz iletişiminde, sosyal medyada en çok gündeme gelen tartışma konularından biri resmi kanallardan yapılan bilgilendirme sürecinin yeteri kadar şeffaf yürütülemediği yönünde olmuştur. Bu çerçevede; Bakan Koca'nın incelenen tarih aralığında, özellikle ilk vakanın tespitiyle birlikte, vakaların durumuna dair bilgileri (şüpheli vakalar ve sayıları, uyrukları, hangi ilde bulundukları, gözlem altında olanlar gibi) adım adım kamuoyuyla paylaştığı görülmüş; şeffaflık tartışmaları noktasında; Bakan Koca resmi duyuruları halk ile en kısa sürede paylaşırken; bilgi ve verilerin daha fazla bilgi alındığında değişebileceği, güncelleneceği bilgisini verdiği de görülmüştür.

Bakan Koca'nın salgın kriz iletişiminde twitteri aktif bir şekilde kullanması sayesinde halk ile çift yönlü bir iletişim kurulmuş; ayrıca paylaşımlarında açık, samimi, konuya hakim, güvenilir ve bilgi paylaşmaya hazır, telkin edici bir dil kullanılmıştır. Bu çerçevede oluşturulan güven zemininde 
yapılan bilgilendirmeler, halkın kuruma, önlemlerine ve kontrol faaliyetlerine şüphe ile yaklaşmamasına katkı sağlaması noktasında önemli bir kriz iletişim stratejisi olarak değerlendirilmektedir.

Sonuç olarak; araştırma kapsamında incelenen tarih aralığında, Sağlık Bakanı Fahrettin Koca'nın twitter paylaşımları, koronavirüs kriz iletişiminde sosyal medya olanaklarını aktif ve efektif olarak kullandığını göstermiştir. Paylaşılan içerikler videolar ve fotoğraflarla zenginleştirilmiştir. Sosyal medya ortamlarının sağladığı özelliklerle bu içerikler paylaşılmıştır, yaygınlaştırılmıştır. Özellikle ilk vakanın tespitiyle, süreç yönetiminde, kaygı ve paniğe yol açmadan kriz iletișim sürecinin en önemli bileșenlerinden olan şeffaflığa dikkat edilerek, sosyal medyada dolașan bilgi kirliliğinin önüne geçilerek, kamuoyunun anlık olarak bilgilendirildiği görülmüștür. İnsan ilişkilerinin zorunlu olarak kısıtlandığ 1 virüsle mücadele sürecinde, sosyal medyanın öneminin ve etkisinin yeniden gündeme geldiği kriz döneminde, Bakan Koca'nın twitter üzerinden yaptı̆̆ 1 paylaşımlarla, sosyal medyanın doğru bir şekilde kullandığında kriz yönetimine katkı sağladığının ve devleti temsilen kuruma olan güvenin oluşmasına ya da pekişmesine olumlu bir etkisi olduğunu göstermiştir.

Sosyal medya ve özellikle araştırma kapsamında odaklanılan twitter, kullanıcılarına sağladığı olanaklar sayesinde kurumların kendilerini daha kolay ifade edebilmesine ve daha kolay destek bulma imkanına sahip olması nedenleriyle, Covid-19 salgını kriz iletişimi sürecinin daha şeffaf, daha hızlı ve daha güvenilir bir şekilde sürdürülmesinde yardımcı olmuştur.

\section{Kaynakça}

Akdağ, M. \& Arklan, Ü. (2013). Kamu Yönetiminde Kriz Yönetimi. Journal of Academic Social Science Studies, 6 (4), 33-35, https://doi.org/10.9761/JASSS822

Arslan, A. (2009). Kriz Yönetiminde Liderlik. Akademik Bakış Uluslararası Hakemli Sosyal Bilimler E-Dergisi, (18), 179-190.

Aslan, P. (2015). Kriz İletişimi Yönetimi, Sosyal Medya ve Liderlik: 'Baltimore Olayları'nda Barack Obama ve Hillary Clinton'ın Twitter Mesajlarına Dair Bir İnceleme. İstanbul Üniversitesi İletişim Fakültesi Dergisi, 0(49), 15-30.

Booth, Simon A. (1993). Crisis Management Strategy. Competition and Change in Modern Enterprises. Routledge Publishing.

Bozkurt, Y. \& Akdeniz, B. (2014). Bir Kamu Yönetimi Sorunsalı Olarak Çevresel Kriz Yönetimi: ABD- Türkiye Karşılaştırması. AIBÜ Sosyal Bilimler Enstitüsü Dergisi, 14(1), 95-114.

Coombs, Timothy W. \& Sherry J., H. (2010), The Handbook of Crisis Communication, Blackwell Publishing.

Çetin, M. \& Toprak, Y. E. (2016). Kriz İletişimi ve Sosyal Medya: Emisyon Krizinde Volkswagen'in Facebook Kullanımı. Selçuk Üniversitesi Illetişim Fakültesi Akademik Dergisi, 9(3), 54-68.

Erkek, S. (2016). Kamu Kurumlarında Sosyal Medya Kullanımı: Sağlık Bakanlığı̈ Örneği. Selçuk Üniversitesi Sosyal Bilimler Enstitüsü Dergisi, (35), 41-150.

Ertaş, H. (2015). 'Kamu Yönetiminde Sosyal Medyanın Kullanımı'. Handan Ertaş (Ed.). Kamu Yönetiminde Sosyal Medya, Kuramdan Uygulamaya. Palet Yayınları.15-42

Fearn-Banks, K. (2011). Crises Communications: A Casebook Approach. Routledge.

Genç, F. (2009). Kriz Yönetimi ve Kamu Yönetiminde Uygulanabilirliği. Verimlilik Dergisi (4), 7 22. 
Gülaslan, T. (2018). Kamu Yönetiminde Sosyal Medya Kullanımı ve Yönetimi: Temel İlkeler ve Öneriler (Yayınlanmamış doktora tezi). Hacettepe Üniversitesi Sosyal Bilimler Enstitüsü.

Gülgün, Sultan B. (2011). Halk Sağlı̆̆ı Krizlerinde Kriz İletişimi ve Kriz Haberciliği: Örnek Olay A/ HIN1 (Domuz Gribi) Pandemisi (Yayınlanmamış yüksek lisans tezi). Ankara Üniversitesi Sosyal Bilimler Enstitüsü.

Kadıbeşegil, S. (2001). Kriz Yönetimi ve İletişimi. Marketing Türkiye, 11 (241), 1 Mayıs 2001

Kaplan, A.M. \& Haenlein, M. (2010). Users of the World, Unite! The Challenges and Opportunities of Social Media. Business Horizons, (53), 59- 68.

Kazanc1, M. (2004). Kamuda ve Özelde Halkla İlişsiler. Turhan Kitabevi.

Keskin, S. ve Baş, M. (2015), "Sosyal Medyanın Tüketici Davranışları Üzerine Etkisinin Belirlenmesi”, Gazi Üniversitesi İ̈BF Dergisi, 17(3), 51-69.

Mazıcı Tanyeri E. (2020). Covid-19 Pandemi Sürecinde Dijital Diplomasi: T. C. Dışşşleri Bakanlığı Üzerine Bir Araştırma. Journal of Turkish Studies, 1087-1104, http://dx.doi.org/10.7827/TurkishStudies.44438

Oğurlu, E. (2020). Tarih Boyunca Pandemiler ve Uluslararası Sisteme Etkileri. Journal of Turkish Studies, 791-805, http://dx.doi.org/10.7827/TurkishStudies.44259

Okay, A. \& Okay, A. Halkla İlişkiler Kavram Strateji ve Uygulamaları. Der Yayınları.

Onat, F. (2010). Bir Halkla İlişkiler Uygulama Alanı Olarak Sosyal Medya Kullanımı: Sivil Toplum Örgütleri Üzerine Bir İnceleme. İletişim Kuram ve Araştırma Dergisi, 0(31), 103-121.

Reynolds, B. \& Seeger, W., M. (2005) Crisis and Emergency Risk Communication as an Integrative Model, Journal of Health Communication; 10(1), 43-55, https://doi.org/10.1080/10810730590904571

Tengilimoğlu, D. \& Öztürk, Y. (2004). İşletmelerde Halkla İlişkiler. Seçkin Yayıncıllk.

Ulutaş, S. (2010). Kriz Yönetimi ve Dönüşümcü Liderlik (Yayınlanmamış yüksek lisans tezi). Dokuz Eylül Üniversitesi Sosyal Bilimler Enstitüsü.

Ural, Güzelcik E. (2006). Stratejik Halkla İlişkiler Uygulamaları. Birsen Yayınevi.

Yayınoğlu, P., Sayımer, İ., Arda, Z. (2007). Belediyelerin Kurumsal Web Sitesi Kullanımı Üzerine Bir İnceleme: Londra Büyükşehir Yönetimi ve İstanbul Büyükşehir Belediyesi Web Sitesi Ana Sayfalarının Karşılaştırılması. Galatasaray Üniversitesi Illetişim Dergisi, (7), 129-157. 